\begin{tabular}{lll} 
KULTURA & $\begin{array}{l}\text { POLSKA A KADEMIA NAUK } \\
\text { KOMITET SOCJOLOGII }\end{array}$ & ISSN 0023-5172 \\
i & $\begin{array}{l}\text { INSTYTUT STUDIÓW POLITYCZNYCH } \\
\text { SPOLECLENSTWO nr } 3 \quad \text { AUTOETNOGRAFIA }\end{array}$ & \\
\hline
\end{tabular}

MICHAE MOKRZAN

Uniwersytet Wrocławski

Katedra Etnologii i Antropologii Kulturowej

\title{
DZIESIĘĆ WYZNAŃ ALBO KRĘPUJĄCY CHIAZM: \\ OD ETNOGRAFII NEOLIBERALIZMU DO NEOLIBERALNEJ ETNOGRAFI**
}

\section{PIERWSZE WYZNANIE ALBO PŁASZCZYZNA WYŁANIANIA}

Chociaż daleko mi do ambicji stworzenia dyskursu inżynierskiego, podzielam przekonanie Claude'a Lévi-Straussa wyrażone w formie retorycznego pytania: „Czyż etnolog pisze coś innego niż wyznania?” (Lévi-Strauss 1984, s. 86). Biorąc za dobrą monetę opinię francuskiego antropologa, a także jego amerykańskiego antagonisty, który w odniesieniu do Smutku tropików napisał, iż „generalnie etnografia jest w części filozofią, w części zaś - a nawet w większości - ma charakter konfesyjny" (Geertz 2005, s. 390), twierdzę, że pisarstwo etnograficzne można traktować jako kolejną, obok spowiedzi i psychoanalizy, opartą na wyznaniu technikę produkowania prawdy, a samego etnografa, na wzór Foucaultowskiego człowieka Zachodu, jako zwierzę wyznające (Foucault 2000a, s. 58; Bert 2008). Dowodzą tego nie tylko wypowiedzi i twórczość przywołanych antropologów, lecz także, a może przede wszystkim, prace pisane w duchu autoetnograficznym. Autoetnografia, będąc w oczach niektórych badaczy i badaczek narzędziem oporu wobec władzy (por. Bielecka-Prus 2014, s. 79), zalana jest wyznaniami, impresjami i introspekcjami. Należy jednak zaznaczyć, że twierdzenie Michela Foucaulta (2000a, s. 59), poczynione

\section{Adres do korespondencji: michal.mokrzan@uwr.edu.pl}

* Niniejszy tekst powstał w ramach grantu badawczego pt. „Retoryczne konstruowanie neoliberalnych podmiotów. Antropologiczna analiza coachingu” finansowanego przez Narodowe Centrum Nauki (UMO-2014/15/D/HS3/00483). 
w kontekście urządzania seksualności, że „produkcję prawdy na wskroś przenikają relacje władzy", można odnieść nie tylko do etnografii realistycznych co czyniono wielokrotnie - lecz także - co jest już raczej rzadkością — do autoetnografii ewokatywnej apologetyzującej wyznanie jako formę terapeutyczną. Przywoływana w pracach autoetnografów ewokatywnych (zob. Ellis, Bochner 2000, 2006) zachęta do tworzenia wyznań często bowiem przyjmuje formę obowiązku moralnego czy wręcz nakazu, które same w sobie mogą rodzić protest („a co, jeśli nie zechcę wyznawać?”), potwierdzając tym samym słuszność rozpoznania Foucaulta. Przywołane oczywistości oraz skrywane aporie wyznaczają granice płaszczyzny dyskursywnej i instytucjonalnej, w której zjawia się to a nie inne wyznanie.

\section{DRUGIE WYZNANIE ALBO CHIAZMATYCZNY OBRÓT SPRAWY}

Gdy w październiku 2014 roku przygotowywałem projekt badań etnograficznych dotyczących procesów konstytuowania podmiotowości opartych na manifestujących się w relacji coachingowej neoliberalnych technologiach urządzania, nie przypuszczałem, że niezamierzonym efektem planowanych badań stanie się tekst naukowy nie tyle poddający neoliberalne praktyki szczegółowej analizie, ile będący owych praktyk produktem. W tytule tego eseju staram się nazwać tę właśnie niespodziewaną woltę, jaka dokonała się pod wpływem moich doświadczeń autoetnograficznych, które miały miejsce podczas trwających dwa lata badań terenowych wśród społeczności profesjonalnych coachów w Polsce oraz osób, które skorzystały z ich usług (coachee).

Tytułowy chiazm, będący figurą słów osiągniętą przez symetryczną zmianę szyku wyrazów (w tym przypadku wyrazów „etnografia” i „neoliberalizm”), wyraża transformację zarówno podstaw teoretyczno-metodologicznych prowadzonych przeze mnie badań, jak i mojego światopoglądu — etnografa odpowiedzialnego za ich prawidłową realizację. Zakładany początkowo cel, by dokonać etnografii neoliberalizmu, został zrealizowany za pomocą działań i strategii, które same określić można mianem neoliberalnych (tj. opartych na imperatywie troski o siebie i myślenia w kategoriach potencjalnych zysków i strat), a poszukiwanym przeze mnie $\mathrm{w}$ terenie neoliberalnym podmiotem okazał się nie tylko menadżer zatrudniony w firmie o zasięgu światowym, lecz także ku mojemu niedowierzaniu i pomimo początkowego sprzeciwu - autor prezentowanych rozważań.

Ów obrót sprawy, w strukturze swej chiazmatyczny, wydaje mi się niezwykle krępujący. Wprawia bowiem mnie - antropologa, którego badania nad coachingiem mogą być postrzegane jako manifestacja antropologii krytycznej, zajmującej się odsłanianiem i podważaniem hegemonicznych relacji w kulturze w pewne zakłopotanie natury teoretycznej i osobistej. Za sprawą doświadczenia autoetnograficznego przedmiot krytycznej analizy został ucieleśniony w osobie samego badacza, stając się siłą napędową popychającą pracę naukową w kie- 
runku nieoczekiwanym, lecz satysfakcjonującym pod względem poznawczym; podważając dotychczasowe założenie o istnieniu rozłamu między przedmiotem poznania a podmiotem poznającym i dyscypliną opisu, a zarazem obnażając moje własne działania i sposób myślenia jako neoliberalne.

Konsternacja połączona $z$ odczuciem zawstydzenia, jakie towarzyszą mi podczas pisania tego tekstu, wiążą się z koniecznością zmierzenia się z niewygodnym problemem: jak zostanie odebrane wyznanie - w którym, jak przypuszczam, odnajdą się także inni badacze i badaczki, jeśli tylko za namową Alvina W. Gouldnera (2010, s. 468) otworzą się „na własne wnętrze” — iż jestem częścią tego, co tak usilnie krytykujemy — zarówno w publikacjach naukowych (por. Burszta, Jezierski, Rauszer 2016; Songin-Mokrzan 2016), jak i w rozmowach kuluarowych - i co gorsza, nie czuję się z tego powodu aż tak źle, jak myślałem, że mogę się czuć.

\section{TRZECIE WYZNANIE ALBO DYSKURS EPIFANICZNY}

Zmierzając tramwajem linii nr 7 na mój pierwszy warsztat coachingowy, w głowie poukładany miałem cały plan badań: wstępne rozumienie przedmiotu poznania, założenia teoretyczne i sposób realizacji badań etnograficznych. Był grudzień 2015 roku, ostatnie dni wietrznej jesieni, tydzień przed Wigilią. Za sobą miałem analizę podręczników coachingu i dobrze wiedziałem, jak coaching definiowany jest przez ich autorów. Zebrawszy różne definicje, mogłem stworzyć własne, wstępne rozumienie coachingu jako interaktywnego procesu zorientowanego na podnoszenie umiejętności, pokonywanie ograniczeń oraz dokonywanie zmian $\mathrm{w}$ życiu zawodowym i osobistym przez jednostki oraz grupy zawodowe. Coaching, jak przekonywali mnie autorzy i autorki czytanych prac, to nie magia i szarlataneria - takie wyobrażenie utrwalały we mnie głosy krytyczne wyrażane $\mathrm{w}$ komentarzach zamieszczanych pod postami satyrycznego profilu poświęconego rozwojowi osobistemu - lecz pełnoprawny zawód, koncentrujący się na technikach i metodach wspierania jednostek bądź grup ludzkich „W ich drodze do osiągnięcia tego, czego pragną, niezależnie od tego, czy jest to konkretny cel, czy po prostu styl życia" (Starr 2011, s. 22). Instruktorzy coachingu wskazywali, że podejmowane w ramach coachingu działania mogą dotyczyć realizacji takich celów, jak: „Stworzenie planu życiowego [...]. Osiągnięcie satysfakcjonującej równowagi między pracą a życiem osobistym" (Starr 2011, s. 20). „Doskonalenie umiejętności marketingowych [...]. Równowaga emocjonalna. Rozwinięcie aspektu kobiecości lub męskości [...]. Integracja aspektu mentalnego, emocjonalnego, duchowego i fizycznego, byś czuł się jak «kompletna osoba». Umiejętność zarządzania sobą" (Przybysz 2009, s. 29-30).

$\mathrm{Z}$ punktu widzenia moich zapatrywań teoretycznych - zaczytywałem się wówczas w twórczości francuskich mistrzów podejrzeń; wszędzie widziałem podmioty znaczące, mikrofizyki władzy i maszyny pożądania - szczególnie frapujący pod względem poznawczym wydał mi się ostatni z wymienionych celów. 
„Umiejętność zarządzania sobą to przecież nic innego jak neoliberalna technologia siebie!" - powiedziałem w uniesieniu do żony, sądząc, że odkrywam Amerykę. W jej spojrzeniu dostrzegłem akceptację — znalazłem swój teren badań! Znalazłem swoje Trobriandy! Mówiąc parodystycznie: mnie też dane było dostąpić objawienia. I jak się miało okazać niebawem, nie była to ostatnia epifania w moim życiu. Dla antropologa, który dotychczas zajmował się przeważnie kwestiami teoretycznymi i „szczekaniem o szczekaniu” — by użyć dotyczącego pisania o pisaniu sformułowania Kennetha Burke’a - chwili tej towarzyszyło olbrzymie poczucie ulgi. „Nie będziesz traktowany poważnie w środowisku, jeśli nie zrobisz prawdziwych badań terenowych" - głos superego huczał mi w głowie $z$ siłą wodospadu. Ów fetysz etnografii, o którym już tyle napisano (Evans-Pritchard 2008, s. 215; Rabinow 2010, s. 19), ma moc stygmatyzacji. To było jeszcze na wstępnym etapie przygotowywania projektu, na rok przed kwerendą biblioteczną, którą odbyłem w listopadzie 2015 roku w The London School of Economics and Political Science. Lektura prac badaczy i badaczek, których pisarstwo doskonale charakteryzuje określenie „efekt Foucaulta” (por. Burchell, Gordon, Miller 1991), miała potwierdzić i utrwalić moją intuicję wpisującą coaching $\mathrm{w}$ kontekst technologii urządzania.

Dla moich badań nad coachingiem kluczowa okazała się koncepcja urządzania, którą sformułował Foucault, inicjując tzw. trzecie teoretyczne przemieszczenie w swojej twórczości (Foucault 2000a, s. 146; Callinicos 1986), polegające na przesunięciu uwagi analitycznej na technologie siebie i ich związek $z$ technologiami władzy. Miejsce styczności między tymi technologiami Foucault określił właśnie za pomocą słowa „urządzanie”, dając tym samym asumpt do wyodrębnienia się $\mathrm{w}$ ramach nauk społecznych studiów koncentrujących uwagę zarówno na dyskursach politycznych podejmujących rozważania nad sposobami zarządzania państwem i administracją, jak i na dyskursach medycznych, filozoficznych, religijnych i pedagogicznych, wiążących się z takimi kwestiami, jak „rządzenie duszami i zachowaniami”, rządzenie dziećmi czy wreszcie rządzenie sobą (Foucault 2000b, s. 163). Czytane z wypiekami na twarzy prace Sama Binkleya - ukąszonego myślą Foucaulta - przyniosły mi pewność, że tą formą urządzania, której powinienem poświęcić uwagę, jest neoliberalizm, rozumiany jako zespół racjonalnych technik pozwalających na zarządzanie podmiotami społecznymi na wzór podmiotów rynkowych. Kotłujące się wówczas we mnie myśli Binkley ujmował następująco (czułem, że czytam najważniejsze zdania $\mathrm{w}$ moim życiu; epifania biorąca się z doświadczenia lektury). W ramach neoliberalnego urządzania, argumentował Binkley, podmiot zachęcany jest do „kształtowania siebie jako autonomiczna, skoncentrowana na sobie jednostka oraz do postrzegania własnych zasobów i predyspozycji w terminach kapitału podlegającego inwestycji i zwrotowi. Neoliberalne urządzanie zakłada istnienie kontinuum obejmującego makrotechnologie, za pomocą których państwa zarządzają populacjami, oraz mikrotechnologie, za pomocą których jednostki zarządzają same sobą. Pozwalając władzy działać "z dystansu", 
jednostki inkorporują racjonalność władzy politycznej i przekładają ją na własne metody prowadzenia siebie" (Binkley 2009, s. 62). Zyskiwałem potwierdzenie wstępnej intuicji. Wyczytana w książce o coachingu „umiejętność zarządzania sobą” okazywała się niczym innym jak ową „metodą prowadzenia siebie"! Konkretnymi materializacjami neoliberalnego urządzania są, jak przekonywał mnie Binkley (2011, s. 96), psychologia pozytywna Martina Seligmana (mówiąca o technikach osiągania szczęścia), inteligencja emocjonalna Daniela Golemana oraz różne formy coachingu.

Jadąc tramwajem linii $\mathrm{nr} 7$, dysponowałem już zatem wstępnym rozumieniem przedmiotu badań: coaching wytwarza podmioty, których funkcjonowanie określa zasada ekonomii zysku oraz troski o siebie. Wiedziałem również, że studia nad urządzaniem nie są wolne od pewnych problemów natury teoretycznej i metodologicznej. W niewystarczającym stopniu pozwalają one bowiem połączyć analizę makrotechnologii (technologii władzy) wytwarzanych $\mathrm{w}$ ramach instytucji i dyskursów eksperckich $\mathrm{z}$ analizą mikrotechnologii (technologii siebie) stosowanych przez aktorów społecznych w praktykach życia codziennego. Studia nad urządzaniem cechuje wręcz skrzywienie teoretyczne polegające na przyjęciu makroperspektywy - macro-level bias, jak ujął zwięźle tę myśl Binkley (2011, s. 84). Koncentrują się one na analizie dyskursów eksperckich, marginalizując doświadczenie konkretnych ludzi. Próby łączenia makroi mikroperspektyw najczęściej kończą się imputowaniem jednostkom sposobów rządzenia sobą, które właściwe są racjonalności instytucjonalnej. Tę charakterystyczną dla studiów nad urządzaniem strategię retoryczną, polegającą na tworzeniu głosu, który kolonizuje „perspektywę przyjmowaną przez realnych ludzi”, Binkley (2014, s. 47) określił mianem „narracyjnego przemieszczenia”. Strategia ta bynajmniej nie rozwiązuje problemu z zakresu teorii i metodologii badań społecznych. Można uznać, że go jedynie maskuje. Wciąż niewyjaśnioną kwestią pozostaje to, w jaki dokładnie sposób jednostki inkorporują instytucjonalne racjonalności? Na czym polega ta praca urządzania, która dokonuje się w szczelinie między makro- a mikrotechnologiami? W jaki sposób konkretni aktorzy społeczni konstytuują się jako podmioty odpowiedzialne, sprawcze i wydajne? W jaki sposób powstaje ów neoliberalny podmiot? Jak uchwycić i opisać to miejsce styczności między technologiami władzy i technologiami siebie, nie powielając błędu „narracyjnego przemieszczenia”? Z takimi pytaniami w głowie mijałem kolejne przystanki. To było jak olśnienie: wglądu w neoliberalną technologię urządzania rozumianą jako praktyka społeczna dostarczą mi badania etnograficzne. Zakładałem, że samo praktykowanie etnografii wykorzystywanie obserwacji uczestniczącej oraz robienie wywiadów z coachami i osobami coachowanymi - pomoże mi w tym. $Z$ takimi myślami jechałem tramwajem linii $\mathrm{nr} 7$. Jechałem $\mathrm{z}$ nadzieją poznania neoliberalnych podmiotów. Jechałem robić etnografię neoliberalizmu!

Myśli te wprawiały mnie w dobre samopoczucie, gdy tramwaj, który mnie przywiózł, znikał już na widnokręgu, zostawiając mnie na zatłoczonym przy- 
stanku niedaleko miejsca, gdzie miał się odbyć mój pierwszy warsztat coachingowy. Przestępując próg sali warsztatowej czułem ekscytację podobną tej taką fantazją żywiłem swoje ego - jakiej doświadczał Bronisław Malinowski, wkraczając po raz pierwszy do wioski na Trobriandach. Byłem trochę przed czasem. Kilka osób rozmawiało przy umieszczonym przy wejściu stole z bufetem. Ktoś podłączał do komputera rzutnik. W środku sali krzesła tworzyły okrąg zająłem jedno $z$ wolnych miejsc, obserwowałem i nasłuchiwałem w oczekiwaniu na rozpoczęcie warsztatu. Po krótkiej autoprezentacji prowadząca warsztat coach powiedziała znamienne dla moich badań słowa: „notujcie, bo myśli nie wrócą". Jak się miało okazać, owa zachęta do tworzenia dyskursu i poszerzania wiedzy de facto była zachętą do pracy nad samym sobą.

\section{TRZY CUDZE WYZNANIA ALBO ETNOGRAFIA PRACY AFEKTYWNEJ}

Od czasu grudniowego warsztatu do chwili, w której piszę te słowa, uczestniczyłem w dwudziestu warsztatach, szkoleniach, kursach i konferencjach coachingowych organizowanych przez cieszące się dużą popularnością i szacunkiem instytucje zajmujące się propagowaniem profesjonalnego coachingu. Obserwowałem zarówno coachów, ćwiczących się w praktykach zawodowych (zadających pytania otwarte, testujących na sobie linie życia, odzwierciedlających), jak i sympatyków coachingu - menadżerów, przedsiębiorców, studentów, nauczycieli akademickich uczestniczących w procesie coachingowym bądź będących już po jego zakończeniu, pragnących zgłębić tajniki coachingu od strony zawodowej lub dążących do osiągnięcia spełnienia, szczęścia i samorealizacji. Obserwowałem zwyczaje, uczyłem się eksperckiego języka, poznawałem gesty - wszystko po to, by zrozumieć nie tylko sposób „w jaki tubylcy widzą świat" (Tyler 1993, s. 30), lecz również samą praktykę społeczną. Jednakże nade wszystko rozmawiałem i słuchałem. Wszak, jak argumentowali Derrida (2002, s. 43) i Tyler (1987, s. 171), podmiot jest podmiotem mówiącym, a moi rozmówcy nie mieli z mówieniem najmniejszego problemu. Coachowie mówili o coachingu i klientach - osobach coachowanych. Klienci zaś mówili o coachingu, coachach i swoim życiu, często przesuwając granice tego, co intymne, poza przyjęte standardy wywiadu etnograficznego, stawiając mnie w niezręcznej sytuacji. Nie byłem przygotowany na zwierzenia dotyczące traumatycznych doświadczeń natury seksualnej, problemów rodzinnych i zawodowych. Za sobą mam sześćdziesiąt wywiadów - ponad siedemdziesiąt godzin cudzych wyznań. Badania etnograficzne nad doświadczeniem związanym z uczestniczeniem $\mathrm{w}$ procesie coachingowym pozwoliły mi stwierdzić, że główną metaforą konceptualną, która organizuje praktyki w ramach coachingu, jest metafora życia jako pracy nad sobą. Dwa pytania problemowe, na które poszukiwałem odpowiedzi w trakcie badań, brzmiały zatem: „na czym polega praca coachów?” oraz „czym się cechuje i jakie korzyści przynosi osobom coachowanym praca nad sobą?". 
Tym, co łączy moich rozmówców-coachów, jest sposób rozumienia coachingu jako praktyki tworzącej lub wzmacniającej istniejące już w kliencie zasoby emocjonalne i kognitywne, dzięki którym będzie on w stanie dokonać transformacji zanurzonego $\mathrm{w}$ przeszłości problemu i osiągnąć zorientowany w przyszłości cel. Bazując na koncepcji Michaela Hardta (2012), pracę wykonywaną przez coachów określiłem mianem pracy afektywnej oferującej niematerialne dobra. Na czym polega owa praca? Nie sposób w paru słowach odpowiedzieć wyczerpująco na to pytanie. $Z$ wielu wyznań na temat coachingu $\mathrm{w}$ pamięci mocno utkwiło mi jedno. Popijając espresso w przepełnionej o tej porze kawiarni, na moje pytanie: Jaką rolę odgrywa coach w relacji coachingowej?, mój rozmówca-coach odparł: najbardziej istotna rzecza z punktu widzenia coachingu to jest moment, kiedy klient uzyskuje wglad, ale klient nie uzyska wgladu albo rzadko uzyska wglad między sesjami. To sa te najbardziej cudowne chwile w pracy każdego coacha, kiedy klient siedzi, siedzi, siedzi i nagle na skutek jednego, drugiego pytania następuje pobudzenie tych wszystkich potączeń $i$ on mówi „wiem, jasne”, kliknęto. [...] Rola coacha jest doprowadzić do sytuacji, żeby powstało to „wow, jasne, już wiem”. [...] żeby klient się skomunikowat ze soba, żeby poszukat w sobie różnych odpowiedzi. [...] Rola coacha jest wspomagać bycie uważnym przez klienta, bo dzięki temu szansa na kliknięcie jest zdecydowanie większa. Jednakże praca coacha nie polega tylko na uruchamianiu potencjału kognitywnego. Coaching to także technologia wyposażająca osoby coachowane w narzędzia wglądu we własne myśli i stany psychologiczne oraz narzędzia do radzenia sobie $z$ emocjami. Jak to metaforycznie ujmuje mój rozmówca: jeżeli ja jestem porwany przez emocje, to ja tracę zdolność myślenia. Czyli ja działając emocjonalnie nie myślę, jestem odcięty od swoich zasobów. [...] I w tym momencie moja rola jest, jakby nauczyć, w jaki sposób sobie radzić z tymi emocjami. [...] Jeżeli ja siedze $w$ kajaku i nie ma $w$ nim wioset, i nagle wpadam gdzieś, w jakiś taki nurt strumienia, to ja jestem porwany i nic nie moge zrobić. Czyli w tym momencie taki coaching to jest nic innego, tylko oddawanie tym ludziom wioset, żeby oni potrafili wśród tych burz i zawieruch trochę lepiej działać". Na tym polega praca afektywna wykonywana przez coachów: wyposażanie klientów we wiosła. Coaching jako Foucaultowski dyspozytyw (zob. Binkley 2011, s. 96).

Wyznania profesjonalnych coachów umocniły mnie w przekonaniu, że etnografia neoliberalizmu powinna przyjąć formę etnografii pracy afektywnej skoncentrowanej na doświadczeniu osób coachowanych. Jeśli moje badania mają mieć przewagę nad studiami nad urządzaniem (przewaga ta polegałaby na tym, by nie popełnić błędu „narracyjnego przemieszczenia”), to kluczową kwestią wydawało się to, by odpowiedzieć na pytanie, w jaki sposób klienci wykorzystują owe wiosła w życiu codziennym. Zależało mi na tym, by uchwycić perspektywę osoby coachowanej.

Epizod z życia pracownika firmy o zasięgu światowym oczekującego na zmianę stanowiska pracy ( $z$ funkcji menadżera na pracownika działu HR) dobrze ilustruje to, czego poszukiwałem podczas badań. Podczas wywiadu moja rozmówczyni-osoba coachowana przywołuje z pamięci ćwiczenie, jakie wyko- 
nała pod wpływem pracy z coachem: Zaczęłam myśleć o zmianie pracy, ponieważ nie mogłam się z moim szefem dogadać. Nie byt dla mnie autorytetem. Nie chciałam za bardzo tego przepracowywać, ale w pewnym momencie jakoś to wylazło i powiedziałam: „Dobra, dzisiaj poświęćmy pót godziny na to, żeby już ten temat zamknać”", bo wiedziałam, że sa inne ważniejsze rzeczy, o których chce porozmawiać, ale to gdzieś mi cały czas wisiało. No $i$ zaczęła się rozmowa na ten temat [z coachem - M.M.] i bardzo szybko się ta rozmowa zamknęta, $w$ takim sensie, że dostałam zadanie, aby napisać list do swojego szefa, $w$ którym po prostu powiem mu wszystko, co bym mu chciała powiedzieć, lub druga opcja, $\dot{z}$ jak będe jechała samochodem, to po prostu $z$ nim pogadam, $w$ cudzysłowie. Jego nie będzie [przy mnie - M.M.], ale po prostu mu wygarnę. I ja tak zrobiłam. Nie napisałam listu. Jestem niecierpliwa. Dla mnie szybsza wersja byto pogadanie sobie $z$ nim. To byto tak, że jak jechałam sama samochodem, to sobie wyobraziłam, że on tam siedzi i zaczęłam mówić mu, jakby, o co mi chodzi i co mi sie nie podoba. I po tej rozmowie, to byto niesamowite też, po tej rozmowie $w$ ogóle przestałam o tym myśléc. Przestałam się ta relacja frustrować. Odpuściłam zupetnie, jakbym zamknęta ten temat. On dalej byt, ja z nim dalej pracowałam, natomiast on już mnie nie denerwowat, nie frustrowat. To byto niesamowite. [...] To nie byta dtuga rozmowa, bo ja jestem taka konkretna osobą. To nie byto tak, że ja gadałam 15 minut do siebie, nie, raczej 5 minut, albo jeszcze krócej. Natomiast niesamowite było dla mnie to, co się stało później, że to tak zadziałało. W zasadzie niewielkim moim wysitkiem nagle nie było tematu. Ja po prostu się ukierunkowatam na tę relację, na to co mnie zżerało wcześniej, ciagnęło energię, a potem, jak już to odpuściłam, to, to gdzieśs tam ta energia poszła $w$ dobra stronę. W wyznaniu tym została podkreślona istotna rola, jaką w zarządzaniu sobą spełnia kompetencja emocjonalna, zdolność rozpoznawania emocji i ich kontrolowania. Przywołane przez moją rozmówczynię „ukierunkowanie” to emiczny trop określający tę afektywną pracę, jaką podczas procesu coachingowego wykonała sama na sobie. Jej doświadczenie związane $z$ udziałem $w$ procesie coachingowym oraz używany do jego opisu język odsłaniają ucieleśnioną logikę neoliberalnej technologii siebie. $Z$ punktu widzenia neoliberalizmu istotne jest to, że dzięki zyskaniu odporności psychicznej kobieta jest w stanie - do czego mnie przekonuje podczas wywiadu - sprawniej realizować cele zawodowe i osobiste.

Przeprowadzona przeze mnie etnografia neoliberalizmu nie pretenduje do całościowego opisu relacji coachingowej. Coaching nie musi za każdym razem prowadzić do pozytywnej transformacji podmiotu. Inna z moich rozmówczyń (coachee) określiła coaching jako „płytką relację” obfitującą we frustrujące momenty. Zadawane przez coacha pytania otwarte w jej przypadku nie przyczyniły się do zmiany postawy, lecz wywołały irytację i, jak to sama określiła, „psychologiczny opór", a w konsekwencji przyjęcie kontestującej postawy wobec działań coacha, którą scharakteryzowała sformułowaniem „weź mnie dalej nie męcz!”. Z pewnością sesje coachingowe mają większy stopień oddziaływania na osoby, które akceptują wyznaczniki neoliberalnej logiki. W słowniku coachingu istnieje nawet termin „coachowalność” (coachability) oznaczający wolę zmiany zachowania $\mathrm{w}$ pożądanym kierunku. Nie będzie wielkim nadużyciem 
stwierdzenie, że termin ten jest blisko spokrewniony z terminem governability, oznaczającym zdolność do bycia zarządzanym i prowadzonym, nie tylko przez innych, ale także przez samego siebie.

\section{SIÓDME WYZNANIE ALBO DOŚWIADCZENIE AUTOETNOGRAFICZNE}

Wiedza na temat pracy afektywnej została uzyskana przeze mnie między innymi za pomocą wywiadów; były to zarówno wywiady ustrukturyzowane, jak i swobodne. Zadawanie pytań i słuchanie tego, co moi rozmówcy mieli mi do powiedzenia, było niezwykle wartościowe pod względem poznawczym. Narracje tworzone $\mathrm{w}$ trakcie wywiadów były bowiem dokonywaną przez nich interpretacją znaczeń, jakie nadawali oni własnym działaniom oraz działaniom innych (Geertz 2005, s. 30). Była to ich własna analiza tego, co jawiło się w ich świadomości. Prowadzone przeze mnie wywiady miały jednak dodatkową wartość. Oprócz tego, że dostarczały mi wiedzy na temat sposobu myślenia i działania, same mogły zostać potraktowane jako technologia siebie. Podczas wywiadów często padały analogie - formułowane przez osoby coachowane - między sesją coachingową a wywiadem etnograficznym. Moje pytania, podobnie jak pytania otwarte coacha, miały siłę perswazji jako zachęta do teoretyzowania nad własnym doświadczeniem. Fakt, że wywiady są czymś więcej niż narzędziem zdobywania materiału etnograficznego, utwierdza mnie w przekonaniu, które zrodziło się już podczas przygotowywania projektu, że wbrew zaleceniom Geertza (2005, s. 30), by nie naśladować działań tubylców, podczas badań powinienem dążyć do tego, by doświadczenie, o którym mi opowiadano, stało się także moim własnym. Nawet najbardziej wścibskie pytania nie rozwiązywały bowiem następującego problemu: ze względów etycznych nie mogłem uczestniczyć w czyichś sesjach coachingowych prowadzonych metodą jeden na jeden. Mogłem tylko o nich słuchać - rozmówcy opowiadali mi o tym, jak jest lub było na sesji coachingowej, jak osoby coachowane działają poza sesjami, jak starają się aplikować wiedzę coachingową do codziennych interakcji — bądź samemu zostać coachem lub skorzystać z usług profesjonalnego coacha.

W konsekwencji etnografię neoliberalizmu uzupełniłem o doświadczenie autoetnograficzne. Autoetnografię, na którą byłem skazany, potraktowałem jako metodę badawczą pozwalającą na rozwiązanie problemu metodologicznego ograniczającego zdolności poznawcze analiz prowadzonych w toku studiów nad urządzaniem. Nie skorzystałem z autoetnografii po to, „aby lepiej zrozumieć siebie w otaczającym świecie" (Kacperczyk 2014, s. 37), ale po to, by lepiej zrozumieć mechanizmy rządzenia sobą. Spośród różnych form autoetnografii najbliżej mi było do autoetnografii analitycznej, która zdaniem Leona Andersona (2014, s. 146) „odnosi się do badań etnograficznych, w których badacz (1) jest pełnym uczestnikiem badanej grupy lub kontekstu (setting), (2) występuje w takiej roli w publikowanych przez siebie tekstach i (3) kieruje się planem badań analitycznych, których celem jest doskonalenie teoretycznych ujęć szer- 
szych zjawisk społecznych”. Byłem konwertytą, używając określenia Andersona, moje pełne uczestnictwo w badanej rzeczywistości wyrastało z moich „początkowo zorientowanych wyłącznie na gromadzenie danych — zainteresowań badawczych danym kontekstem, które w toku prowadzonych badań" prowadziły mnie „do całkowitego zanurzenia się w badanym [...] świecie i przyjęcia [...] roli jego pełnego uczestnika" (Anderson 2014, s. 150-151). Właściwie już samo uczestnictwo $\mathrm{w}$ warsztatach coachingowych wymuszało na mnie pełne zaangażowanie w przedmiot badań. Warsztaty te bowiem najczęściej są zorganizowane tak, by móc wcielać się raz w rolę coacha, a raz w rolę osoby coachowanej. Na własnej skórze zacząłem doświadczać coachingu. Jako coach uczyłem się zadawać pytania, tworzyć oparte na zaufaniu porozumienie $z$ klientem, uważnie słuchać oraz stosować narzędzia coachingowe. Jako coachee - wyznawałem i dbałem o siebie.

Poniżej przywołane wyznanie zostało sporządzone przeze mnie w czerwcu 2016 roku, tuż po powrocie do domu po pierwszym dniu trwania dwudniowego warsztatu dotyczącego coachingu prowokatywnego. Nie chcąc przekraczać bezpiecznej granicy intymności, z prezentowanego wyznania usunąłem środkowy fragment poświęcony doświadczeniu tacierzyństwa. Wyznanie to traktuję na równi z wypowiedziami moich rozmówców, dlatego też zapisuję je innym krojem czcionki: Doświadczenie autoetnograficzne. Doświadczenie progowe. Doświadczenie ekstremalne. Chcac zrozumieć to "jak myśla tubylcy?”, choć w tym przypadku należałoby powiedzieć, ,jak odczuwaja tubylcy?”, zgłositem się na ochotnika do roli klienta podczas prezentacji sesji coachingowej w grupie warsztatowej. Chciatem doświadczyć tego, czego doświadczaja klienci. Myślowo, uczuciowo, emocjonalnie, cieleśnie. Poniosło mnie. Opowiedziałem coachowi o swoim "problemie” w obecności grupy. Mówiłem o lęku, a zatem o doświadczeniu ekstremalnym, będacym na granicy coachingu i psychoterapii. Powiedziałem dużo osobistych rzeczy. Za dużo. Nie chciałem aż tak bardzo się otworzyć, ale pod wptywem całej sytuacji, działania coacha, powiedziałem za dużo. Owszem, chciałem doświadczyć, jak moga się czuć klienci wobec coachów, a także, jak moi rozmówcy-klienci moga się czuć przede mna, gdy opowiadają o rzeczach ważnych $i$ intymnych (nie byty to zatem do końca szczere motywacje, zwtaszcza że tylko dwie osoby na dziewięć — w tym coach — wiedziaty wówczas, że jestem etnografem), ale nie spodziewatem się, że moge stracić nad tym kontrolę. Puścity hamulce - zanurzytem się w tym doświadczeniu. Pod wpływem coacha lub dzięki samej sytuacji coachingowej zaczałem mówić o rzeczach, z których istnienia nie zdawałem sobie sprawy. A może one nie istniaty wcześniej? Stworzyłem je? Jeśli je stworzytem, nie oznacza to jednak, że sa one fałszywe. Raczej narracja powotata je do życia. Jaki ma status ontologiczny to, o czym mówiłem? To byt performance! Nie ma znaczenia poprzedzającego sam czyn. No wtaśnie, jaki charakter miało to, o czym mówiłem? A o czym mówiłem? O moim doświadczeniu tacierzyństwa. [...]. Z perspektywy czasu mam wattpliwości, czy wymyślitem ten problem pod wpływem chwili, czy też może to jest faktycznie mój problem i potrzebuję wsparcia? Czuje, że mówitem kliszami psychologicznymi. To, że na końcu powiedziałem, że wtaściwym problemem jest problem relacji rodzicielskiej, byto klisza i diagnozowaniem się za pomoca tej kliszy psychologicznej. Od- 
wołałem się do dyskursu eksperckiego. Gadałem, potrzebowałem uszu, które mnie wystuchaja. Co odczułem po zakonczeniu sesji? Skołowanie, zawstydzenie, lęk - obnażytem się przecież przed nieznajomi ludźmi. Do tej pory to inni się przede mna obnażali. Zmienito to moja perspektywę na wywiady z klientami. Czułem rozbicie emocjonalne zwiazane $z$ obnażeniem się. Pojawity się myśli, czy może lepiej nie kontynuować warsztatów, by nie widzieć tych ludzi, albo skłamać przed nimi, że to, o czym mówitem, nie było prawdą. Gdy piszę te słowa jest 23.46. Myślę o doświadczeniu Kirsten Hastrup związanym z kanibalizmem antropologicznym.

Trwająca ponad półgodziny sesja z coachem (która dla zgromadzonych osób miała mieć charakter instruktażowy, chodziło bowiem o zaprezentowanie tego, jak uprawiać prowokatywną odmianę coachingu) była przełomowa dla prowadzonych przeze mnie badań; dzięki temu doświadczeniu zyskałem status, używając określenia Roberta Mertona (1988, s. 18, cyt. za: Anderson 2014, s. 150), „ostatecznego uczestnika”, czyli badacza, który występuje w podwójnej roli uczestnika i obserwatora. Było to doświadczenie o charakterze liminoidalnym. Nie tyle zmienił się mój status społeczny, ile zacząłem o sobie myśleć w innych kategoriach. Dotychczasowa etnograficzna identyfikacja została zmodyfikowana przez kolejną: ,jestem coachee".

Gdy analizuję ten krótki zapis doświadczenia progowego z punktu widzenia autoetnografii analitycznej, to istotne wydają się nie tyle emocje, jakie towarzyszyły mi podczas owej sesji - ze względu na fakt, że przystąpiłem do sesji jako etnograf, który chciał się czegoś dowiedzieć o coachingu, nie mogę ich uogólniać w celu nadania sensu złożonemu doświadczeniu - ile ukute przeze mnie impresje: Pod wptywem coacha lub dzięki samej sytuacji coachingowej zaczątem mówić o rzeczach, $z$ istnienia których nie zdawałem sobie sprawy. A może one nie istniaty wcześniej? Stworzyłem je? Jeśli je stworzytem, nie oznacza to jednak, że sa one fatszywe. Raczej narracja powołała je do życia. [...] Odwołatem się do dyskursu eksperckiego. Gadatem, potrzebowałem uszu, które mnie wystuchają. Impresje te pozwalają mi skonstatować, że coaching należy umieścić obok - omówionych już wyczerpująco przez Foucaulta - chrześcijańskiej spowiedzi oraz sesji psychoanalitycznej. Wszystkie trzy formy wyznania są technologiami siebie, w których jednostka zobligowana jest do wyjawiania prawdy o sobie w obecności eksperta od duszy: księdza, psychoterapeuty, coacha. „Stanowimy jedyną cywilizację - pisze Foucault w Historii seksualności (2000a, s. 16-17) - w której kompetentne osoby otrzymują zapłatę za słuchanie czyichkolwiek zwierzeń [...] jako że chęć mówienia i oczekiwany zysk daleko wykraczają poza możliwości zwykłego słuchacza, niektórzy oddają w najem własne uszy". Praca coacha, jak potwierdzało to moje doświadczenie progowe oraz wypowiedzi coachów i osób coachowanych, w gruncie rzeczy polega na uważnym słuchaniu tego, co klienci mają do powiedzenia.

„Podczas typowej sesji coachingowej szkolony powinien zwykle mówić przez mniej więcej 70\% czasu" (Starr 2011, s. 97) — zalecenie sformułowane przez autorkę podręcznika coachingu odpowiadało także mojemu doświadcze- 
niu. To bowiem coachee ma określać cele i tworzyć plan działania - wszystko to oczywiście odbywa się w mowie. Mówienie prawdy to jednakże nie tylko kwestia deskrypcji, jak wskazuje Tina Besley (2005, s. 85): „z tego względu, że język ma funkcję performatywną, mówienie prawdy o sobie również tworzy, konstytuuje lub konstruuje formy samego siebie". Udział w instruktażowej sesji coachingowej pozwolił mi uzupełnić tę myśl o jedną kluczową dla moich badań obserwację: za sprawą aktu mowy, jakim jest wyznanie, osoba coachowana nie tylko tworzy swoje Ja, lecz również je kontestuje. Analiza doświadczenia progowego pokazała, że moją uwagę przyciągnęły w szczególności figury charakterystyczne dla genus iudiciale tzn. takiego rodzaju mowy sądowej, który polega na oskarżeniu i atakowaniu. Moje publiczne wyznanie wypełnione było bowiem figurami accusatio (z łac. oskarżenie) - wytykałem sobie wady i ujawniałem skrywane przewinienia. Jednakże za sprawą działań coacha, jego zmuszających do myślenia zdań, które celowo wyolbrzymiały skalę "problemu", zacząłem bronić się przed tak krytycznym osądem. Moja praca nad sobą zaczęła przypominać działanie adwokata — odpierałem zarzuty, które jeszcze przed chwilą stawiałem samemu sobie, używałem figur refutacyjnych. Ja, które wytwarzałem podczas tego performansu, było efektem działań symbolicznych, skatalogowanych przez starożytne studia nad retoryką w postaci pięciu działów: inwencji, dyspozycji, elokucji, zapamiętania i akcji. Ja - coachee jako homo rhetoricus (por. Oesterreich 2009, s. 54). Podczas mojego wyznania, które było mieszaniną donosu, oskarżenia, obrony i afirmacji, nieświadomie i w sposób niesystematyczny wykorzystywałem różne gatunki i kategorie retoryczne: wynajdywałem myśli (inwencja), próbowałem je porządkować (dyspozycja), ubierałem je w słowa (elokucja), tworzyłem opowieść (narratio), a raz nawet użyłem entymematu, a wszystko po to, by — jak mówi jeden ze sloganów krążących w środowisku coachów i osób coachowanych - „być lepszą wersją siebie”, co w moim przypadku oznaczało po prostu, by być lepszym tatą.

Moje doświadczenie autoetnograficzne, uzupełnione o badania etnograficzne wśród społeczności coachów i osób coachowanych, dało mi podstawy, by uznać, że w procesie czynienia podmiotów odpowiedzialnymi i wydajnymi nie mamy do czynienia z jakąśs "alchemią", jak to ujął Binkley (2014, s. 152) sprawiając mi tym samym wielki zawód, ponieważ sądziłem, że odwołując się do prac Pierre'a Bourdieu będzie on w stanie rozwiązać kwestię pracy urządzania za pomocą bardziej precyzyjnego określenia - ale $z$ działaniami retorycznymi per se. Lata spędzone na studiowaniu niełatwej twórczości Stephena Tylera (choć słowo „niełatwa” użyte w kontekście The Unspeakable zakrawa na kolosalny eufemizm) zaowocowały kolejnym objawieniem - i piszę te słowa bez cienia ironii. Bazując na konstatacji poczynionej przez Tylera wraz z Ivo Streckerem (Strecker, Tyler 2009, s. 5), iż „za pomocą retoryki możemy wyczarować te idee, wartości, zasady moralne i prawa, które stanowią podstawę kultury", mogłem z dużą pewnością siebie argumentować, że to dzięki retoryce dokonuje się połączenie między technologiami władzy a technologiami siebie. 
Miejsce styczności między tymi technologiami jest ze swej natury retoryczne! Odkrycie to powinno obronić prezentowane tu doświadczenie autoetnograficzne, taką żywię nadzieję, przed potencjalnym oskarżeniem o bycie wątpliwym „pod względem poznawczym” (Songin 2011, s. 158). Cel uprawianej przeze mnie autoetnografii pokrywa się bowiem - przynajmniej do tej pory - z celem autoetnografii analitycznej, o którym Anderson pisze, że nie jest nim „dokumentacja osobistych doświadczeń, aby zaprezentować "perspektywę insidera» ani też wywołanie w czytelniku emocjonalnego rezonansu. Specyficzną cechą analitycznie zorientowanych nauk społecznych jest raczej wykorzystywanie danych empirycznych do uzyskania wglądu w pewne szersze zjawiska społeczne niż te dostarczane przez dane same w sobie" (Anderson 2014, s. 158).

Poniżej przywołane doświadczenie autoetnograficzne znacznie komplikuje dotychczasowe rozpoznania prowadzone $\mathrm{w}$ paradygmacie zarówno etnografii neoliberalizmu, jak i autoetnografii analitycznej.

\section{DZIEWIĄTE WYZNANIE ALBO UCIELEŚNIONA LOGIKA NEOLIBERALIZMU}

Chcąc uzyskać pełniejszy wgląd w mechanizmy neoliberalnego urządzania, w końcu przystąpiłem do pełnowymiarowej sesji coachingowej. W październiku 2016 roku rozpocząłem w towarzystwie profesjonalnego coacha proces coachingowy, który trwał przez trzy miesiące. Wreszcie mogłem powiedzieć: „mój coach”. Na pierwszą sesję przyszedłem już z jasno zdefiniowanym celem. Cieszyłem się, że mój stopień coachowalności jest wysoki. Celem procesu było „stworzenie planu działania na najbliższe półtora roku”. Tak sformułowany cel wpisałem do formularza kontraktu. Każdy proces - o czym wiedziałem już z wywiadów - powinien zostać zakontraktowany. Kontrakt jest narzędziem dyscyplinującym i motywującym obie strony relacji. Coach bowiem zobowiązuje się $\mathrm{w}$ nim do realizowania $\mathrm{z}$ pełną starannością i zaangażowaniem swojej pracy, ja - coachee - zaś do bycia sumiennym, kreatywnym, szczerym i odpowiedzialnym za swoje decyzje, działania i uzyskany efekt. W dodatkowej rubryce poświęconej sposobowi prowadzenia procesu wpisałem: „bez żartów seksistowskich i homofobicznych”. Złożenie podpisu na dwóch egzemplarzach kontraktu od razu skojarzyłem $z$ działaniem performatywnym. Retoryczna moc obietnicy.

Pod enigmatycznym w gruncie rzeczy sformułowaniem „stworzenie planu działania na najbliższe półtora roku" rozumiałem między innymi obmyślenie sposobu dalszej realizacji projektu badawczego poświęconego coachingowi, włączając $\mathrm{w}$ to takie zadania, jak: dokończenie przeprowadzenia wywiadów z coachami i osobami coachowanymi, zakodowanie wywiadów i stworzenie listy kodów, przygotowanie referatów konferencyjnych, napisanie trzech artykułów na temat coachingu i dokończenie jednego oraz napisanie szkicu monografii. Moje sesje coachingowe w gruncie rzeczy były poświęcone temu, jak wydajniej zarządzać czasem; jak przy całkowitym zaangażowaniu w pracę naukową 
zachować równowagę między pracą zawodową a życiem osobistym. Przywoływane $z$ dużą częstotliwością przez moich rozmówców (osoby coachowane) uczucie frustracji wynikające $z$ przeświadczenia o marnowaniu czasu i towarzyszącemu mu marzeniu, by doba trwała 48 godzin, mnie także było bliskie. Jak połączyć z sobą pracę na uczelni (obowiązek prowadzenia działalności dydaktycznej oraz realizowania dodatkowych czynności natury administracyjnej) z pracą naukową (konieczność i zarazem przyjemność realizacji projektu badawczego) i życiem osobistym (spędzaniem czasu z żoną i rosnącą w zastraszającym tempie córką)? Odczuwana przeze mnie konieczność postawienia takiego pytania już sama w sobie manifestowała siłę oddziaływania neoliberalnej logiki. Odpowiedź na to pytanie musiałem sformułować sam. Coach, jak mówią o tym liczne kodeksy i podręczniki profesjonalnego i etycznego coachingu, nie może za mnie myśleć i działać; może mnie jednak zainspirować lub zachęcić do myślenia i działania poprzez zadanie kluczowego pytania; może zaproponować mi także narzędzia, które będę w stanie wykorzystać. W tym względzie mój proces był podobny do procesów, o których opowiadali mi moi rozmówcy. Ja także największą pracę musiałem wykonać samotnie pomiędzy sesjami. Wiedzę i narzędzia do wydajniejszego zarządzania czasem musiałem zastosować w praktyce. Do gustu przypadły mi w szczególności dwa takie narzędzia: używam ich dzisiaj, pisząc ten artykuł.

Pierwsze $z$ nich to często wykorzystywana w coachingu tzw. macierz Eisenhowera, polegająca na rozplanowaniu działań ze względu na ich ważność i pilność. Macierz Eisenhowera klasyfikuje czynności w czterech grupach. W grupie I mieszczą się działania ważne i pilne, które należy wykonać jak najszybciej. Mogą one wiązać się z sytuacjami kryzysowymi, w moim przypadku takimi jak przekroczony (w listopadzie 2016 roku) o tydzień czas przesłania redaktorom ukończonego artykułu. Grupa II klasyfikuje działania ważne, ale nie pilne, na których wykonanie jest jeszcze czas. Takim działaniem było oczywiście sporządzenie szkicu monografii na temat neoliberalnych technologii urządzania mój główny cel — oraz przygotowanie artykułów (w tym tego, który czytelnik/czytelniczka w tym momencie czyta). Grupa III to działania pilne, ale mało ważne z punktu widzenia realizacji głównego celu: rachunki, sprzątanie, prowadzenie oficjalnej strony i profilu na Facebooku jednostki naukowej, w której jestem zatrudniony. W grupie IV zawierają się działania mało ważne i mało pilne: tzw. pożeracze czasu (oglądanie seriali oraz surfowanie po internecie). Podczas realizacji projektu czułem dyskomfort z powodu istnienia działań, które odciągały moją uwagę od prowadzenia badań terenowych i pisania. Działania mało ważne i mało pilne oraz działania pilne, ale mało ważne doprowadzały mnie do frustracji. Na zadane samemu sobie pytanie, ,jak chciałbym, aby wyglądała moja praca nad projektem?”, odpowiedziałem: „chcąc wydajnie pracować muszę lepiej zarządzać działaniami z grupy III i IV".

Działania te wyobrażałem sobie jak usuwany — raz na tydzień bądź czasami częściej w zależności od skali nieporządku — kurz. Wiedziałem, że jeśli chcę 
efektywnie pracować, dookoła mnie musi być czysto. „Jak skutecznie pozbyć się kurzu?" - pytanie to urastało niemalże do rangi zagadnienia egzystencjalnego. Jak powszechnie wiadomo, nie ma sposobu na pozbycie się kurzu raz na zawsze — to jest jego istotą. Co mogłem zatem zrobić? Musiałem nauczyć się z nim żyć. Zacząłem go sukcesywnie usuwać, a przede wszystkim przestałem brudzić. Metafora sprzątania wyrażała sens i emocje towarzyszące wykonywanej przeze mnie pracy afektywnej - choć nie mam zdiagnozowanej amathofobii, na myśl o czającym się w kącie kłębku kurzu dostaję spazmów. W prowadzonych przeze mnie wywiadach moi rozmówcy podawali własne tropy podejmowanej pracy: „przewinięcie”, „prostowanie się”, „wydeptywanie nowej ścieżki”, ja natomiast miałem „sprzątanie”.

Jak wyglądała owa praca? Wszystkim działaniom przeze mnie podejmowanym przyświecała myśl o ich opłacalności z punktu widzenia efektywnej realizacji projektu i, co za tym idzie, osiągnięciu awansu zawodowego. Czynności nieopłacalne, jak ów kurz, musiały zostać sprzątnięte. Uekonomicznienie relacji społecznych i troska o siebie. Grzecznie, lecz stanowczo odmówiłem napisania recenzji artykułów. Zrezygnowałem z uczestniczenia w czasochłonnych pracach katedralnego Zespołu ds. Jakości Kształcenia — przed podjęciem tej decyzji na samo hasło „KRK” reagowałem alergicznie. Za przyzwoleniem redaktora naczelnego przestałem angażować się $\mathrm{w}$ prace redakcji czasopisma. Zrezygnowałem także $z$ prowadzenia oficjalnego profilu jednostki naukowej na Facebooku, a do pomocy w redagowaniu strony internetowej dokooptowałem kilka osób. Nie podjąłem wyzwania bycia promotorem pomocniczym pracy doktorskiej. Co kluczowe z punktu widzenia neoliberalnej technologii siebie, wszystkim tym działaniom odmownym nie towarzyszyły pojawiające się zazwyczaj u mnie w takich kontekstach wyrzuty sumienia i negatywne emocje, które skutecznie odciągałyby mnie od realizacji głównego celu. Poradziłem sobie z nimi. Zajęcia na uczelni skomasowałem w jednym dniu (przychodziłem do pracy o 7:30, a wychodziłem o 18:00), by pozostałe cztery dni tygodnia móc w pełni przeznaczyć na badania i pisanie. Przestałem oglądać do późna w nocy seriale - wolałem się wyspać, by następnego dnia móc pracować produktywniej. Natomiast czynności, z których nie mogłem zrezygnować, starałem się uprzątnąć przed właściwą pracą, by uniknąć „efektu Zeigarnik”. Zamiatanie pod dywan nie wchodziło $\mathrm{w}$ grę - zawsze bowiem spod dywanu mógł wydostać się jakiś paproch, doprowadzając mnie tym samym do frustracji. Sprzątnięcie nieopłacalnych działań, oprócz tego, że pomagało w efektywnej realizacji projektu, miało jeszcze jedną dodatkową korzyść - znalazłem czas dla rodziny i na małe przyjemności. Angażując się jedynie w pracę, nawet w tę najbardziej ekscytującą, nie osiągniemy zamierzonych efektów; musimy odpocząć, by nabrać sił do realizowania zadań. W pełni zinternalizowałem dyskurs ekspercki. Byłem i wciąż jestem ucieleśnioną logiką neoliberalizmu.

Drugim narzędziem zarządzania czasem - narzędziem, które podczas pisania tego tekstu nadal motywuje mnie do wydajniejszej pracy — jest miesz- 
czący się na jednej kartce papieru półroczny kalendarz projektowy. Doskonale pamiętam tę chwilę. Pewnego dnia wietrznej jesieni zaopatrzyłem się w sklepie papierniczym $\mathrm{w}$ arkusz papieru o formacie B1 (wysokość $100 \mathrm{~cm}$ i szerokość $70,7 \mathrm{~cm}$ ) i udałem się do domu, by wykonać ów kalendarz. Arkusz papieru ułożyłem na stole i zacząłem kreślić pionowe i poziome linie: siedem linii pionowych (na poszczególne dni tygodnia) oraz 40 linii poziomych (na konkretne tygodnie). Pracowałem $z$ wielkim zaangażowaniem. Jak zazwyczaj mój stosunek do tego typu czynności jest - mówiąc eufemistycznie - sceptyczny, tak wtedy byłem w pełni przekonany do tego, co robię. Rysowanie linii traktowałem $z$ powagą, o czym przekonały mnie uczucia pojawiające się $\mathrm{w}$ chwili, gdy podczas wpisywania numerów dni pomyliłem się i musiałem zetrzeć gumką wszystkie cyfry, by móc dorysować kilka linii poziomych. Praca fizyczna nad przygotowaniem kalendarza zajęła mi około dwóch godzin. W kratkę ostatniego dnia czerwonym flamastrem i drukowanymi literami wpisałem najważniejszy cel — „MANUSKRYPT”. W trakcie realizacji projektu w kalendarz wpisywałem także cele pośrednie (przygotowanie artykułów, zakodowanie wywiadów) oraz działania ważne i pilne, a także działania pilne, ale mało ważne. Kalendarz ów zawiesiłem w pokoju, tak bym mógł codziennie na niego patrzeć. Sama jego obecność działa na mnie motywująco, zachęca mnie do tego, by wydajniej pracować, by zmieścić się w czasie, działać zgodnie $z$ harmonogramem. I nawet jeśli do końca marca, który miał zakończyć się zrealizowaniem zadania opracowania ostatnich dziesięciu wywiadów, pozostawały mi trzy dni - stawałem na głowie, by zrealizować to zadanie w wyznaczonym terminie. Kalendarz jest czymś, co moi rozmówcy nazywali „wewnętrznym coachem”. Motywuje mnie. Nakłania do działania. Czy też mówiąc precyzyjniej, to ja sam przekonuję siebie, zachęcam i nakłaniam do podejmowania określonych działań. Przecież nikt mnie do tego nie zmusza, to ja sam dobrowolnie - słowo to oddaje sposób rozumienia neoliberalizmu jako „rządzenia przez wolność” (Rose 1999, s. xxiii) - zrobiłem ów kalendarz i realizowałem oraz realizuję nadal wpisane w niego działania (w tym pracę nad artykułem, który czytelnik/czytelniczka ma przed oczami). Wykonywana przeze mnie praca afektywna — praca nad sobą przyjmuje postać autoperswazji. Jest to forma retoryczna oparta na koncepcji retoryki jako namowy do czynu (ad agendum) i zmiany postawy (Burke 2008, s. 36). To właśnie autoperswazja okazuje się tym miejscem styczności między technologiami władzy a technologiami siebie, które Foucault określił mianem urządzania!

Chcąc wzmocnić efekt niniejszych słów, raz jeszcze powtórzę: byłem i wciąż jestem ucieleśnioną logiką neoliberalizmu. Fakt, że mój proces coachingowy wykorzystałem do tego, by móc przygotować plan działania dotyczący realizacji badań antropologicznych na temat doświadczenia coachingowego, komplikuje dotychczasowe rozpoznania w kwestii etnografii neoliberalizmu i autoetnografii analitycznej. Nawet odwołanie się do ekstremalnego doświadczenia Loïca Wacquanta (2003), który pisząc o boksie sam zaczął trenować boks, czy 
Leona Andersona (2014) — socjologa-spadochroniarza piszącego o spadochroniarzach, nie jest $\mathrm{w}$ stanie ująć skali i ciężaru zagadnienia, z którym przyszło mi się zmierzyć. Zdobyta przez tych badaczy wiedza i umiejętności na temat boksu i spadochroniarstwa nie wpłynęły bezpośrednio na sposób prowadzenia przez nich badań i pisania na ich temat. Ja skorzystałem $z$ coachingu, by zdobyć wiedzę, jak sprawniej zarządzać sobą w celu zrealizowania projektu badawczego na temat coachingu. Pomocy w robieniu etnografii neoliberalizmu, czy też szerzej mówiąc, pomocy w procesie wytwarzania wiedzy na temat przedmiotu badań, dostarczył mi sam przedmiot badań. Coś na kształt systemu autopojetycznego. To już nie etnografia neoliberalizmu czy autoetnografia analityczna, lecz neoliberalna etnografia. Neoliberalne urządzanie opisujące samo siebie? Czymże zatem jest tekst, który czytelnik ma przed oczami?

\section{DZIESIAৃTE WYZNANIE ALBO NEOLIBERALNA TECHNOLOGIA SIEBIE}

$\mathrm{Na}$ wstępnych stronach drugiego tomu Historii seksualności Foucault wyznaje, że ów tom, którego tytuł brzmi Użytek z przyjemności, można potraktować jako technologię siebie. Uprawiana przez Foucaulta refleksja filozoficzna nad estetykami istnienia sama jest " "ascezą", ćwiczeniem siebie w myśleniu” (Foucault 2000a, s. 149). Choć ten esej, który powstaje niejako na marginesie książki na temat neoliberalnych technologii urządzania, nie ma pretensji filozoficznych, to $z$ wyznaniem Foucaulta łączy go właśnie idea troski o siebie (por. Dallas 2012). Technika siebie — jak tłumaczy tę myśl Foucault — to praktyka, która pozwala „jednostkom dokonywać, za pomocą własnych środków bądź przy pomocy innych, pewnych operacji na własnych ciałach oraz duszach, myślach, zachowaniu, sposobie bycia, operacji, których celem jest przekształcenie siebie tak, by osiągnąć pewien stan szczęścia, czystości, mądrości, doskonałości czy nieśmiertelności" (Foucault 2000c, s. 249).

Esej ten można zatem potraktować jako hermeneutyczną i terapeutyczną próbę przepracowania kłopotliwych kwestii natury teoretycznej i emocjonalnej. Jest to $z$ jednej strony problematyzacja nowej sfery doświadczenia, która wyłania się pod wpływem zastosowania autoetnografii (w jej odmianie analitycznej) jako metody i techniki zdobywania materiału. Z drugiej zaś strony realizacja jednego $z$ postulatów autoetnografii ewokatywnej, by celem badań naukowych było prowokowanie zmian poprzez wywoływanie emocji w sobie i w czytelnikach. Jeśli nawet tymi emocjami miałyby być wstyd oraz niepokój. Wstyd wynikający z faktu, że tekst, który czytelnik czyta - być może nawet z uczuciem lekkiego zażenowania - jak Sartre'owskie „ciało dla drugiego”, uwypukla napięcie między „tym, co intymne, a tym, co odsłonięte” (Tischner 1995, s. 79). Niepokój zaś — z konfrontacji z wątpliwością: „,czy tam, gdzie podmiot rozrasta się tak bardzo, nie kurczy się przedmiot?" (Geertz 2000, s. 111); wątpliwość, dla której Geertz znalazł stosowną nazwę: hipochondria dzienników. 
Niech dotychczasowe wyznania nie przysłonią jednakże tego, co strategiczne: 14 punktów - oto stawka $\mathrm{w}$ publicznym ćwiczeniu siebie $\mathrm{w}$ oswajaniu wzajemnego powiązania wstydu i niepokoju. Za taką cenę za opłacalne uznałem pisanie o sobie oraz pisanie $\mathrm{w}$ pierwszej osobie liczby pojedynczej — pisanie, które zawsze wydawało mi się problematyczne i niestosowne ze względu na sposób, w jaki rozumiem ,ja”. „Ja” to „efekt znaczącego”; i jeśli owo „ja” zyskuje przeświadczenie o swojej subiektywności, sprawczości i autentyczności to tylko poprzez zapomnienie faktu, że źródłem wiedzy „ja” o sobie jest coś w stosunku do niego zewnętrznego - Inny jako obraz lub język (Stavrakakis 2009, s. 372). Solidaryzuję się zatem w kwestii rozumienia ,ja” z Judith Butler, która w Przedmowie do Uwikłanych w płeć wyznała: „Nie uważam, że poststrukturalizm oznacza śmierć pisarstwa autobiograficznego; zwraca on natomiast uwagę na trudności «ja», by wyrazić się w języku, którym dysponuje. Bo przecież «ja», które czytelnik/czytelniczka tu napotyka, jest częściowo wynikiem gramatyki decydującej o dostępności osoby w języku. Nie znajduję się poza językiem, który nadaje mi strukturę, lecz jednocześnie nie jestem zdeterminowana przez język, który owo «ja» umożliwia” (Butler 2008, s. 30). Z uczuciem ulgi przyjmuję wyznanie Butler. Usprawiedliwia, rozgrzesza i mam nadzieję, że także chroni przed potencjalnymi oskarżeniami o narcyzm i solipsyzm (Songin 2011, s. 158) prezentowaną tu narrację pierwszoosobową. Narrację, która jest materializacją neoliberalnej logiki polegającej na uekonomicznieniu pisania i realizacji idei troski o siebie (por. Bröckling, Krasmann, Lemke 2011, s. 25).

\section{BIBLIOGRAFIA}

Anderson Leon, 2014 [2006], Autoetnografia analityczna, tłum. Maja Brzozowska-Brywczyńska, „Przegląd Socjologii Jakościowej”, t. 10 (3), s. 144-166.

Bert Jean-François, 2008, Michel Foucault i etnologia: kilka uwag o kulturze wyznania, tłum. Urszula Filimon-Kucharska, w: Agnieszka Chwieduk, Adam Pomieciński (red.), Francuska antropologia kulturowa wobec problemów wspótczesnego świata, Wydawnictwo Naukowe PWN, Warszawa.

Besley Tina, 2005, Foucault, Truth Telling and Technologies of the Self in Schools, „Journal of Educational Enquiry", t. 6 (1), s. 76-89.

Bielecka-Prus Joanna, 2014, Po co nam autoetnografia? Krytyczna analiza autoetnografi jako metody badawczej, ,Przegląd Socjologii Jakościowej, t. 10 (3), s. 76-95.

Binkley Sam, 2009, The Work of Neoliberal Governmentality: Temporality and Ethical Substance in the Tale of Two Dads, „Foucault Studies”, t. 6, s. 60-78.

Binkley Sam, 2011, Psychological Life as Enterprises: Social Practice and the Government of Neo-liberal Interiority, „History of the Human Sciences”, t. 24 (3), s. 83-102.

Binkley Sam, 2014, Happiness as Enterprise: An Essay on Neoliberal Life, State University of New York Press, New York.

Bröckling Ulrich, Krasmann Susanne, Lemke Thomas, 2011, From Foucault's Lectures at the Collège de France to Studies of Governmentality: An Introduction, w: Ulrich Bröckling, Susanne Krasmann, Thomas Lemke (red.), Governmentality: Current Issues and Future Challenges, Routledge, New York, London.

Burchell Graham, Gordon Collin, Miller Peter (red.), 1991, The Foucault Effect: Studies in Governmentality, University of Chicago Press, Chicago. 
Burke Kenneth, 2008, Tradycyjne zasady retoryki, tłum. Krzysztof Biskupski, w: Marek Skwara (red.), Retoryka, słowo/obraz terytoria, Gdańsk.

Burszta Wojciech Józef, Jezierski Piotr, Rauszer Michał (red.), 2016, Zwodnicze imaginarium: antropologia neoliberalizmu, Wydawnictwo Naukowe Katedra, Gdańsk.

Butler Judith, 2008, Uwikłani w płeć. Feminizm i polityka tożsamości, tłum. Karolina Krasuska, Wydawnictwo Krytyki Politycznej, Warszawa.

Callinicos Alex, 1986, Foucault's Third Theoretical Displacement: Technologies of the Self , „Theory, Culture and Society", t. 3 (3), s. 171-177.

Dallas Roger, 2012, Research, Practice, and the Space Between Care of the Self Within Neoliberalized Institutions, „Cultural Studies. Critical Methodologies”, t. 12 (3), s. 242-254.

Derrida Jacques, 2002, Marginesy filozofii, tłum. Adam Dziadek, Janusz Margański, Paweł Pieniążek, Wydawnictwo KR, Warszawa.

Ellis Carolyn, Bochner Arthur P., 2000, Autoethnography, Personal Narrative, and Reflexivity: Researcher as Subject, w: Norman K. Denzin, Yvonna S. Lincoln (red.), Handbook of Qualitative Research, wyd. 2, Sage, Thousand Oaks.

Ellis Carolyn, Bochner Arthur P., 2006, Analyzing Analytic Autoethnography: An Autopsy, „Journal of Contemporary Ethnography", t. 35 (4), s. 429-449.

Evans-Pritchard Edward Evan, 2008, Czary, wyrocznie i magia u Azande, tłum. Sebastian Szymański, Państwowy Instytut Wydawniczy, Warszawa.

Foucault Michel, 2000a, Historia seksualności, tłum. Bogdan Banasiak, Tadeusz Komendant, Krzysztof Matuszewski, Czytelnik, Warszawa.

Foucault Michel, 2000b, Rządomyślność, tłum. Damian Leszczyński, Lotar Rasiński, w: Michel Foucault, Filozofia, historia, polityka, Wydawnictwo Naukowe PWN, Warszawa-Wrocław.

Foucault Michel, 2000c, Techniki siebie, tłum. Damian Leszczyński, Lotar Rasiński, w: Michel Foucault, Filozofia, historia, polityka, Wydawnictwo Naukowe PWN, Warszawa-Wrocław.

Geertz Clifford, 2000, Dzieło i życie. Antropolog jako autor, tłum. Ewa Dziurak, Sławomir Sikora, Wydawnictwo KR, Warszawa.

Geertz Clifford, 2005, Interpretacja kultur. Wybrane eseje, tłum. Maria Piechaczek, Wydawnictwo Uniwersytetu Jagiellońskiego, Kraków.

Gouldner Alvin W., 2010, Kryzys zachodniej socjologii, tłum. Paweł Tomanek, Nomos, Kraków.

Hardt Michael, 2012, Praca afektywna, tłum. Piotr Juskowiak, Krystian Szadkowski, „Kultura Współczesna", nr 3, s. 83-93.

Kacperczyk Anna, 2014, Autoetnografia - technika, metoda, nowy paradygmat? O metodologicznym statusie autoetnografii, „Przegląd Socjologii Jakościowej, t. 10 (3), s. 32-74.

Lévi-Strauss Claude, 1984, Jan Jakub Rousseau, tworca nauk humanistycznych, tłum. Leszek Kolankiewicz, „Twórczość”, nr 6, s. 80-89.

Merton Robert K. 1988, Some Thoughts on the Concept of Sociological Autobiography, w: Matilda White Riley (red.), Sociological Lives, Sage, Newbury Park, CA.

Oesterreich Peter L., 2009, Homo Rhetoricus, w: Ivo Strecker, Stephen Tyler (red.),Culture and Rhetoric, Berghahn Books, New York-Oxford.

Przybysz Agnieszka, 2009, Przyciagnij sukcesy z pasją. Twoja droga do sukcesu: wspaniała kariera, biznes z pasja, wolność finansowa, radość życia, Coaching Institute, Warszawa.

Rabinow Paul, 2010, Refleksje na temat badan terenowych w Maroku, tłum. Karolina J. Dudek, Sławomir Sikora, Wydawnictwo Marek Derewiecki, Kęty.

Rose Nikolas, 1999, Governing the Soul: The Shaping of the Private Self, Free Association Book, London-New York.

Songin Marta, 2011, Doświadczenie etnograficzne i polityka usytuowania, w: Marcin Kafar (red.), Biografie naukowe. Perspektywa transdyscyplinarna, Wydawnictwo Uniwersytetu Łódzkiego, Łódź. 
Songin-Mokrzan Marta, 2016, Transformacja uniwersytetu. „Kultury audytu” i neoliberalne technologie zarzadzania podmiotami społecznymi, „Kultura i Edukacja”, nr 3, s. 242-257.

Starr Julie, 2011, Podręcznik coachingu. Sprawdzone techniki treningu personalnego, tłum. Agata Trzcińska, Oficyna a Wolters Kluwer Business, Warszawa.

Stavrakakis Yannis, 2009, Lacanowski podmiot: niemożliwość tożsamości i centralność identyfikacji, tłum. Maciej Kropiwnicki, w: Lotar Rasiński (red.), Jezzk, dyskurs, społeczeństwo, Wydawnictwo Naukowe PWN, Warszawa.

Strecker Ivo, Tyler Stephen, 2009, Introduction, w: Ivo Strecker, Stephen Tyler (red.), Culture and Rhetoric, Berghahn Books, New York-Oxford.

Tischner Józef, 1995, Dramat cielesności-krajobraz wstydu, „Znak”, nr 8, s. 76-87.

Tyler Stephen, 1987, The Unspeakable. Discourse, Dialogue and Rhetoric in the Postmodern World, The University of Wisconsin Press, Wisconsin.

Tyler Stephen, 1993, Wprowadzenie do metod antropologii kognitywnej, tłum. Olga Kubińska, w: Michał Buchowski (red.), Amerykańska antropologia kognitywna, Instytut Kultury, Warszawa.

Wacquant Loïc, 2003, Body and Soul: Notebooks of an Apprentice Boxer, Oxford University Press, New York.

\title{
TEN CONFESSIONS, OR, AN EMBARRASSING CHIASMUS: FROM THE ETHNOGRAPHY OF NEOLIBERALISM TO NEOLIBERAL ETHNOGRAPHY
}

\author{
Michał Mokrzan \\ (University of Wrocław)
}

\section{Summary}

The subject of this essay is the constituting of subjectivity as reflected in neoliberal technologies of management manifesting themselves in the coaching relationship. This question is addressed on the basis of ethnographic research conducted among coaches and persons being coached in Poland. However, the form of the essay goes beyond the qualitative framework of traditional ethnographic research. In regard to autoethnographic experience, the initial goal of making an ethnography of neoliberalism was achieved though actions and strategies that in themselves could be described as neoliberal (that is, conducted in terms of the imperative of self-concern and thinking in categories of potential gains and losses).

\section{Key words / słowa kluczowe}

ethnography of neoliberalism / etnografia neoliberalizmu, studies in governmentality / studia nad urządzaniem, affective labor / praca afektywna, technologies of the self / technologie siebie, coaching 